\title{
GROWTH AND SURVIVAL OF PIONEER AND LATE SUCCESSIONAL SPECIES IN SIMULATED LIGHT ENVIRONMENTS IN A SRI LANKAN LOWLAND RAIN FOREST
}

\author{
'PAKAK Panditharathna, 'BMP Singhakumara and ${ }^{2}$ PMS Ashton \\ ${ }^{4}$ Department of Forestry and Environmental Science, \\ University of Sri Jayewardenepura, Nugegoda \\ ${ }^{2}$ School of Forestry and Environmental Studies, Yale University, New Haven, U.S.A.
}

Growth and survival of two pioneer and four late successional species in different light levels in shade houses were investigated over a period of one year from January 2000 to January 2001 at the Sinharaja field research station.

Schumacheria castaneifolia (Dilleiliaceae) and Vitex altissima (Verbenaceae) represented the pioneer species. Psychotria nigra, Caertnera vaginans (Rubiaceae), Syzygium operculatum and $S$. rubicundum and (Myrtaceae) vere selected as late successional species. The four late successional species were further sibdivided into two canopy species ( $S$. operculatum and $S$. rubicundum) and two understorey species (Psychotria nigra and Gaertnera vaginans) based on height at maturity of their parent trees. Seedlings were grown under four light environments (full sun, 1200; partial sun, 800; partial shade, 350; shade, $50 \mu \mathrm{molm}^{-2} \mathrm{~s}^{-1}$ ) that represented a range of PPFD (photosynthetic photon flux density) found within the forest. Five seedlings of each species were grown in each light environment, which was replicated three times. At the end of one year the height increments and percentage survival of seedlings were measured.

The study revealed that two Syzygium species, Gaertnera vaginans and S. castaneifolia showing the lowest height increments when grown in shade. But no significant difference was observed between shade and full sun for these species. Although the lowest height increments for $V$. altissima and $P$. nigra were observed in full sun and in partial shade respectively, there is no significant difference among shade, partial sun and full sun for $V$. altissima. Psychotria nigra did not show any significant difference among four light treatments. The greatest relative height growth was observed in partial shade for G. vaginans and S. castaneifolia, V. altissima, and in partial sun for two Syzygium species. Plasticity (ratio between highest and lowest values among light treatments) measurement of height increment was highest in $G$. vaginans (3.47), the lowest in $P$. nigra (1.52) compared to $S$. operculatum (1.79), S. rubicundum (2.18), V. altissima (2.19), $S$. castaneifolia (3.08). Percentage seedling survival of $S$. castaneifolia, and $V$. altissima was $100 \%$ under all light levels. All species survived equally well in partial sun light level. In shade, seedling survival of G. vaginans, and $S$. operculatum was $93 \%$ and in Psychotria nigra, it was $80 \%$. G. vaginans and $P$. nigra showed $93 \%$ seedling survival in partial shade. In full sun $G$. vaginans and $S$. rubicundum exhibited $93.3 \%$ survival while $P$. nigra showed $67 \%$ survival.

These results suggest that pioneer species grow and survive well in all light levels than late successional species in early stage of their life cycle. 